Al-Bayyinah: Journal of Islamic Law-ISSN: 1979-7486 (p); 2580-5088 (e) Volume VI Number 2, pp. 29-42

\title{
KONFLIK DAN KETENANGAN DALAM HUKUM ISLAM ANTARA IDEALISME DAN REALISME
}

\section{Baharuddin Basettu}

(Dosen Tetap STAIN Watampone, Sulawesi Selatan, Indonesia, email: baharuddinbasettu@gmail.com)

\section{Abstract}

Islam as universal religion, is not limited by time and place, the Koran states that the scope of application of Islamic teachings are for all mankind, human beings wherever it is. Therefor, Islam should be accepted by every human being without having a "conflict" in which Islam as a religion it must be peksibel for dealing with plural and modern society, he was required to be able to face the challenges of the times.

Differences of opinion among scholars that happened viewed by the Orientalists as a precedent, they consider it as a law and said the Islamic law as a legal scholar. Differences of opinion among scholars is seen as a conflict in the law. Coulson's view of Islamic law are dealt with in six lectures delivered at the University of Chicago, and one was reffered to the conflict between idealism and realism.

\section{Kata Kunci: Hukum Islam, Ketenangan dan Realisme}

\section{PENDAhULUAN}

Agama samawi sebelum Islam mempunyai kapasitas jangkauan waktu dan tempat yang terbatas-batas temporer itu dibatasi dengan kehadiran nabi setelahnya, seperti ajaran Musa as. dead line-nya adalah ketika ajaran Isa as. datang berbeda. Berbeda dengan itu, agama Islam yang dibawa oleh Nabi Muhammad saw. merupakan agama terakhir dan penutup. 
Islam sebagai agama yang universal, tidak terbatas oleh waktu dan tempat tertentu, al-Qur'an menyatakan bahwa lingkup keberlakuan ajaran Islam adalah untuk seluruh umat manusia, dimanapun manusia itu berada. ${ }^{1}$ Oleh sebab itu, Islam seyogyanya dapat diterima oleh setiap manusia tanpa harus ada "konflik" dengan keadaan dimana manusia itu berada. Mengingat Islam akan berhadapan dengan masyarakat plural, modern, sebagaimana Islam telah berhadapan dengan masyarakat yang bersahaja. Maka, ketika Islam berhadapan dengan masyarakat plural dan modern, ia dituntut untuk dapat menghadapi tantangan zaman.

Secara sosiologis, diakui bahwa masyarakat senantiasa mengalami perubahan yang dapat mempengaruhi pola pikir dan tata nilai yang ada pada masyarakat. Bahwa semakin maju cara berfikir, suatu masyarakat akan semakin terbuka untuk menerima kemajuan ilmu pengetahuan, sains dan teknologi. Kenyataan ini dapat menimbulkan masalah, terutama apabila kegiatan itu dihubungkan dengan norma-norma agama. Sehingga, pemecahan atas masalah tersebut, bahwa syari'at Islam dapat dibuktikan tidak bertentangan dengan syari'at Islam sangat sesuai untuk setiap masyarakat, dimana dan kapanpun mereka berada.

Gambaran tentang kemampuan syari'at Islam dalam menjawab segala persoalan modern dan kesalahpahaman oleh para orientalis dalam memahami maksud-maksud syari'at, dapat diketahui dengan mengemukakan beberapa prinsip syari'at Islam mengenai tatanan hidup baik secara vertikal (antara manusia dengan Tuhannya) maupun secara horisontal (antara

${ }^{1}$ Lihat QS. Saba (34): 28 dan QS. al-Anbiya (21): 107

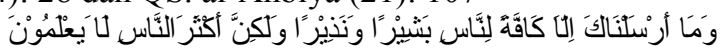

Terjemahnya:

Dan Kami tidak mengutus kamu, melainkan kepada umat manusia seluruhnya sebagai pembawa berita gembira dan sebagai pemberi peringatan, tetapi kebanyakan manusia tidak mengetahui.

Terjemahnya:

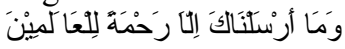

Dan tiadalah Kami mengutus kamu, melainkan untuk (menjadi) rahmat bagi semesta alam. 
sesama manusia). ${ }^{2}$ Sebagai kriteria, ${ }^{3}$ syari'at tidak bisa dihadapkan kepada canda akal manusia melainkan harus dijaga dalam identitasnya yakni kesempurnaan.

Sejumlah orientalis yang mengkritik syari'ah karena kelakuannya dan juga mengatakan bahwa syari'ah bersifat idealistis yang terhindar dari positivisme. Dalam bukunya, History of Islamic Law, Coulson menyatakan bahwa yurisprudensi Islam dapat berhasil memecahkan masalah hukum dan masyarakat hanya apabila yurisprudensi itu bebas dari tujuan hukum agama yang diekspresikan dalam pengertian totaliter dan bertentangan. Dengan pernyataannnya ini, Coulson bermaksud menyatakan bahwa syari'at harus berhenti dari kedudukannya sebagai hukum agama maupun sebagai pengontrol masyarakat yang merupakan tujuan utamanya sebaliknya dia katakan bahwa syari'ah kini harus dikontrol oleh masyarakat dengan melayani kepentingannya, sehingga dengan demikian syari'ah akan dipandang sebagai hukum dalam arti sebenarnya. ${ }^{4}$ Pendapat orientalis yang salah itu dikarenakan fakta bahwa kebaikan itu dapat diketahui secara rasional dan hukum harus ditentukan oleh kebutuhan-kebutuhan sosial.

Perbedaan pendapat yang terjadi dikalangan ulama dipandang oleh para orientalis sebagai preseden, mereka menganggapnya sebagai hukum dan mengatakan hukum Islam sebagai hukum ulama. Perbedaan pendapat dikalangan ulama inilah yang dipandang sebagai konflik dalam hukum. Pandangan Coulson tentang hukum Islam tersebut dibahasanya dalam enam kuliahnya yang disampaikan di University of Chicago, dan salah satu konflik yang dimaksud adalah antara idealisme dan realisme.

${ }^{2}$ T. M. Hasbi Ash-Shiddieqy, Fakta Keagungan Syari'at Islam (Cet. II; Jakarta: Tintamas, 1982), h. 23.

${ }^{3}$ Q.S. Al-Furqan (25): 1

Terjemahnya:

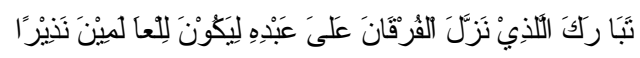

Maha suci Allah yang telah menurunkan Al-Furqan (alQur'an) kepada hamba-Nya. Agar dia menjadi pemberi peringatan kepada seluruh alam.

${ }^{4}$ Muhammad Maslehuddin, Philosophy of Islamic Law and The Orientalist A Comparative Study of Islamic Legal System (Lahore: Ashfaq Mirza, Mg. Director, Islamic Publication Ltd., t. th.), h. 68. 


\section{PEMBAHASAN}

\section{Konflik antara Idealisme dan Realisme}

Berbicara tentang konflik dan ketegangan yurisprudensi Barat yang pada dasarnya merupakan produk dari berbagai macam filsafat hidup dan ideologi politik yang telah menemukan polanya dalam peradaban Barat yang kemudian berbeda pandangan tentang nilai-nilai tertinggi dan tujuan hidup manusia.

Yurisprudensi Islam menurut Coulson adalah keseluruhan proses dari aktivitas intelektual yang memastikan dan menemukan kehendak Tuhan yang ditransformasikan ke dalam hak dan kewajiban yang secara hukum dapat dilaksanakan. Selanjutnya Coulson beranggapan bahwa pendapat ahli hukum sebagai hukum. ${ }^{5}$ Hukum Islam adalah sistematis dan komprehensif, maka bagi siapa yang hendak menemukan pertentangan dan ketegangan di dalamnya adalah tidak benar karena mereka tidak mampu membedakan sumbersumber aturan dari sumber-sumber tambahan serta tidak memahami maqashid syari'ah.

Pada periode Umayyah, secara umum ditandai dengan pengangkatan para hakim untuk menyelesaikan perselisihan dengan kemampuan yang tidak dibatasi untuk memutuskan kasus-kasus yang dihadapi berdasarkan pendapat pribadi. Tidak ada pengaruh penyeragaman yang ditekankan oleh pemerintah dan tidak ada Hirarki pengadilan yang mengikat presedenpreseden yang mungkin menyeragamkan sistem dalam menanggapi suatu kasus. ${ }^{6}$ Karena kemampuan nalar dan tingkat pengetahuan serta kesalehan benar-benar tergantung pada apa yang dimiliki sang hakim. Bahkan pada masa ini hukum Tuhan tunduk pada akal yang dapat merusak dan mengubah hukum.

\section{${ }^{5}$ Ibid., h. 155.}

${ }^{6}$ Pemerintahan Bani Umayyah sebagai raja yang bersifat otokrasi, yang didominasi oleh pendapat pribadi mereka dalam mengambil keputusan politik, ekonomi dan diplomatik. Tetapi pengecualian bagi Umar bin Abd Aziz yang dicatat tidak hanya karena hukum dan hadis Nabi. W. Montgomery Watt, Islam and The Integration of Society (Edinburgh: University Press, 1972), h. 249. Lihat pula H. Muh. Zuhri, Hukum Islam dalam Lintasan Sejarah (Cet. I; Jakarta: PT Raja Grafindo Persada, 1996), h. 49-53. 
Dimana pemerintah Bani Umayyah, administrasi hukum dilaksanakan dala pengadilan-pengadilan oleh para qadi' yang diangkat oleh khalifah, yang dipilih dari ulama. Disamping itu pemerintah membentuk pengadilan khusus yang disebut pengadilan muzhalin. Pengadilan ini dimaksudkan untuk memperbaiki kesalahan-kesalahan personil penguasa dan para pejabat pemerintah. Peran khalifah secara pribadi memutuskan perkara dan memberi keadilan menurut kebijakannya. Lembaga peradilan lain yang dibentuk adalah wilayah al-Hisbah yang berfungsi untuk menjaga pelanggaran moralitas dan menanggulangi kasus-kasus yang terlihat dalam kehidupan sehari-hari, seperti; penyelewengan timbangan di pasar barangbarang tiruan, kecurangan dagang dan lain-lainnya.

Dimasa ini, orang Islam pada umumnya melihat bahwa persoalan fiqh adalah persoalan keagamaan semata, yang otomatis hanya dikuasai oleh ulama. Maka fikih yang mereka perhatikan adalah keputusan ulama, aturan yang dibuat oleh penguasa temporal seolah bukan persoalan agama, kendati untuk membuatnya membutuhkan persetujuan ulama milik pemerintah.

Akhirnya orang-orang Bani Umayyah sebagai penguasa dicela karena tidak memperdulikan prinsip-prinsip fundamental hukum, yang mengakibatkan Bani Abbasiyah berkuasa pada tahun $132 \mathrm{H}^{8}$ Periode Abbasiyah adalah periode yang baik untuk mempelajari hukum Islam, mengingat pada periode ini beberapa aliran hukum muncul dimana yang monumental diantaranya adalah empat aliran sunni yaitu Abu Hanifah, Malik bin Anas, Syafi'i dan Ahmad bin Hanbal.

Menginjak periode modern, menurut Moslehuddin modernisasi dalam Islam pada dasarnya merupakan suatu gerakan taklid atau peniruan buta terhadap masa lampau yang menghendaki ijtihad, bahwa adalah interpretasi rasional alQur'an untuk memenuhi kebutuhan masyarakat sekarang. ${ }^{9}$ Para modernis menilai bahwa Islam tidak memerlukan sistem yang membantu (tradisional) yang dianggap hanya merintangi kemajuan berfikir dan bahkan batasan-batasan teologi kuno

${ }^{7}$ H. Muh. Zuhri, Ibid., h. 80.

${ }^{8}$ W. Montgomery Watt,op. cit., h. 250.

${ }^{9}$ Muhammad Moslehuddin, op. cit., h. 56. 
tentang batasan-batasan ilmu dikesampingkan. Sehingga dimulailah suatu usaha menghilangkan pegangan konsep tradisional dengan jalan keluarnya harus berdasarkan akal dan rasionalisme. Gerakan ini membawa momentum dan dikatakan bahwa hukum Islam yang asalnya dari Tuhan tidak mampu berkembang dan beradaptasi dengan kondisi modern dan hanya menjadi hukum ulama Islam. ${ }^{10}$ Untuk sekarang, kaum modernis memperbolehkan liberalisme dalam Islam dan reinterpretasi rasional tentang al-Qur'an, bagi mereka hadis-hadis Nabi ketinggalan zaman. Mereka menanggapinya dengan kurang respek jika hadis-hadis itu bertentangan dengan ide-ide mereka, karena yang mereka inginkan adalah hukum Tuhan harus menyesuaikan dengan keinginan mereka.

Pada intinya, sorotan Coulson mengenai idealisme dan realisme ini adalah bahwa hukum Islam merupakan hukum yang bersifat idealistis dan jauh dari realis, Coulson lebih menunjukkan kepada prakek-praktek hukum Islam itu sendiri yang lebih mendominasi pada masalah administrasi hukum melalui kantor-kantor pengadilan di beberapa negara Islam.

Coulson memberikan beberapa contoh, misalnya terhadap jabatan hakim dengan berbagai keputusannya,

"Coulson menilai bahwa hukum timbul dari keputusan pengadilan yang aktual oleh Nabi dan para khlifah seperti Umar. Bahwa fuqaha pada masa awal dalam mazhab hukum sering merupakan orang-orang yang berpandangan praktis. Coulson menegaskan bahwa dengan terjadinya perdebatan Yurisprudensi yang dimulai pada awal abad ke VIII dan akhirnya menghasilkan teori tentang sumber-sumber hukum, menimbulkan pengertian bahwa syari'ah merupakan sistem perintah-perintah Tuhan yang menyeluruh dan ditetapkan lebih dulu, suatu sistem hukum yang memiliki eksistensi independen dari masyarakat, tidak timbul dari masyarakat tetapi diturunkan kepada masyarakat. Penemuan hukum murni ini, begitu yang dirasakan merupakan tugas yang paling baik yang dilakukan secara terpisah dari praktek. Kemudian Yurisprudensi Islam secara esensial menjadi ilmu introspektif yang membicarakan perluasan hukum syari'ah namun secara abstrak dan suka

\footnotetext{
${ }^{10}$ Ibid., h. 66.
} 
meninggalkan urusan duniawi bagi pelaksanaan ajaran yang dijelaskan kepada pejabat negara. Idealisme fuqaha abad pertengahan ini, yang mengadopsi tugas penasehat spritual bagi penyadaran Islam daripada para pelaksana praktis urusan-urusan itu, menciptakan suatu perbedaan yang nyata antara doktrin hukum dan praktek hukum maupun antara tugas fuqaha dan tugas hakim. Karena itu, dalam Islam ada ketegangan khusus antara teori hukum dengan realitas sosial". 11

Berkaitan dengan pandangan Coulson di atas, Moeslahuddin mengkritik dan menilainya keliru tentang ulamaulama yang memulia perdebatan yurisprudensi dan konsep syari'ah sebagai sistem perintah-perintah Tuhan yang ditentukan lebih dulu dan sebagai sistem yang tidak tumbuh dari masyarakat tetapi justru diturunkan kepada masyarakat dari atas bukanlah karya baru melainkan membentuk dasar-dasar syari'ah sebagaimana diajarkan Nabi dan para sahabat terutama khulafa al-Rasyidin dan ortodoks. ${ }^{12}$ Lebih lanjut Moeslahuddin mengomentari, bahwa syari'ah merupakan hukum Allah yang merupakan suatu standar untuk menentukan tindakan-tindakan manusia yang harus dijaga bentuk idealnya dan tidak ditentukan oleh kenyataan-kenyataan sosial yang tunduk pada perubahan.

Kalau diperhatikan pendapat Coulson dan kritikan Moeslahussin tampaknya perbedaan diantara keduanya terjadi karena perbedaan dalam melihat antara doktrin hukum dan praktik hukum maupun antara tugas fuqaha dan tugas hakim. Menurut Moeslahuddin realitas sosial yang ditekankan Coulson tidak lain adalah suatu gejala yang berubah sedangkan syariah telah ada sejak lama, haruskan syari'ah diubah menurut konsep perubahan realitas. Hukum Allah selamanya tidak berubah sebagai suatu pola yang harus diikuti apa adanya sebagaimana dalam QS. al-A'raf (7): 3

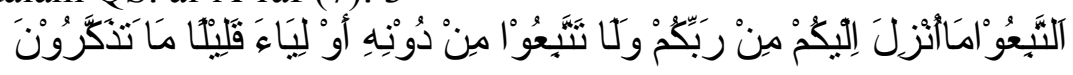

Terjemahnya:

Ikutilah apa yang diturunkan kepadamu dari Tuhanmu dan janganlah kamu mengikuti pemimpin-pemimpin selain-

\footnotetext{
${ }^{11}$ Ibid., h. 167.

${ }^{12}$ Ibid.
} 
Nya. Amat sedikitlah kamu mengambil pelajaran (daripadanya).

Kemudian Coulson mengangkat kasus hukum keluarga, bahwa hukum keluarga sekarang ini telah dimodifikasi secara mendasar dengan berbagai cara, untuk menyesuaikan diri dengan perubahan standar dan nilai-nilai masyarakat sekarang. Karena itu peraturan-peraturan tentang prosedur dan bukti yang mengikat pengadilan juga telah berubah; pola doktrin tradisional yang idealistik dan kaku telah dikendorkan dalam berbagai hal. ${ }^{13}$

Kekuasaan politik raja, katanya digunakan untuk melindungi pengadilan-pengadilan syari'ah dari pegambilan keputusan dalam persoalan-persoalan kebapakan yang berdasarkan pada praduga tradisional tertentu yang jelas. Hukum tradisional Hanafi mengakui anggapan yang menyatakan bahwa masa kehamilan bisa berlangsung selama dua tahun dan oleh Malik menyatakan lima tahun. Tetapi melihat di zaman modern, berdasarkan pendapat medis, bahwa masa kehamilan paling lama adalah satu tahun. Disini Coulson menilai hukum syara' tradisional menunjukkan ketidakadilan. Misalnya, seorang anak yang dilahirkan oleh seorang janda selama dua tahun setelah suaminya meninggal akan dianggap sebagai anak sah suaminya terdahulu sehingga ia berhak, mewarisi sebagian besar harta peninggalannya. Orang-orang yang berusaha untuk menolak tuntutan anak yang diragukan ini akan mengingkari tanggung jawab pembuktian yang hampir tidak mungkin itu sebenarnya tidak sah.

Menurut Coulson lagi, karena itu untuk memperbaiki hal ini dan kejahatan-kejahatan yang lain, maka hukum Mesir tahun 1929 diundangkan dan pengadilan tidak memperdulikan perselisihan yang menurut legitimasi terhadap anak yang lahir lebih dari satu tahun setelah berakhirnya perkawinan ibu dengan orang yang dinyatakan sebagai ayah. ${ }^{14}$

Berkenaan dengan contoh yang dikemukakan Coulson, Moeslahuddin menilainya, sebagai orang yan tidak dapat membedakan antara pendapat fuqaha dan hukum. Karena contoh yang disajikan Coulson, memegangi pendapat fuqaha

\footnotetext{
${ }^{13}$ Ibid., h. 169.

${ }^{14}$ Ibid., h. 169
} 
mengenai masa kehamilan pada kasus tersebut sebagai hukum, padahal pendapat-pendapat mereka jauh daripada hukum. ${ }^{15}$ Maka untuk mengetahui realitas yang sesungguhnya menurut QS. al-Ahqaf (46): $15^{16}$ dan QS. al-Baqarah (2): $233{ }^{17}$ Ini sesuai dengan fakta-fakta ilmiah.

Dengan demikian hukum merupakan kejelasan yang sesuai dengan fakta-fakta ilmiah, tetapi apa yang Coulson kemukakan sesungguhnya mengabaikan hukum dan hanya bertumpu pada pendapat para ulama. Selain itu, Coulson tidak menghubungkan atau menganalisis secara mendalam dengan sumber utamanya. Sehingga usahanya untuk membuktikan bahwa hukum Islam itu tidak realistis atau tidak dapat dipraktekkan menimbulkan kesan bahwa sesungguhnya Coulson tidak memahami hukum.

Pada bidang mu'amalah, ada beberapa prinsip perdagangan yang telah diambil oleh syari'ah berdasarkan hukum darurat, seperti menemukan alternatif bagi asuransi dan bebas bunga bank. Karena syari'at adalah hukum yang sempurna dan berlaku sepanjang masa. Oleh Coulson menunjuk dan menekankan pada realisme, baginya realisme adalah bahwa syari'ah ditentukan oleh fakta-fakta sosial dan bahwa riba' (bunga), transaksi spekulatif diperbolehkan ia mengatakan:

"Juga ada bidang-bidang tertentu dari ajaran riil syari'ah, dimana idealisme para fuqaha tidak sesuai dengan kondisi kehidupan praktis. Mungkin contoh yang paling jelas terlihat pada ajaran riba. Pada dasarnya larangan bunga, konsep riba, telah diperluas secara jelas dan sistematis oleh para fuqaha

${ }^{15}$ Misalnya Abu Hanifah yang mendasarkan pendapatnya pada pernyataan Aisyah yang menyatakan bahwa masa kehamilan itu harus dua tahun, tetapi oleh Malik memperpanjang dengan empat tahun dan juga berdasarkan pada pernyataan tetangganya (isteri Muhammad Ibn Ajalan) bahwa ia hamil tiga kali yang masing-masing kehamilan berjalan selama empat tahun.

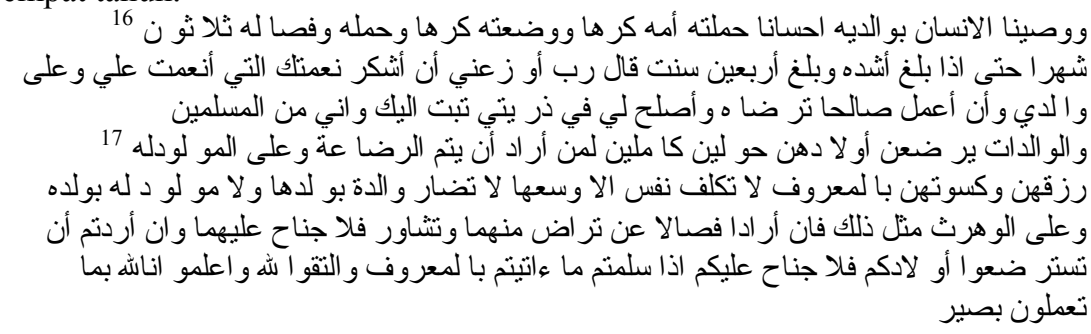


untuk mencakup, yang karenanya menghalangi, bunga apa pun atas pinjaman uang atas penanaman modal. Lebih lanjut, berhubung doktrin itu dilengkapi dengan larangan umum atas transaksi-transaksi penjudian, maka tercakup dalam jangkauannya semua jenis transaksi spekulatif, yang hasilnya, dipandang dari segi kepentingan material yang berkembang dalam anggota masyarakat, tidak dapat diramal secara tepat. Jadi hukum telah menolak, dari pola idealnya tentang sesuatu, bentuk-bentuk kontrak dan transaksi bisnis yang dalam praktek merupakan urat nadi perdagangan dan ekonomi."18

Oleh Moslehuddin menilai Coulson salah ketika mengatakan bahwa riba' pada dasarnya merupakan larangan terhadap bunga (peminjaman dengan bunga tinggi), karena riba' bermakna pertambahan atau kelebihan atas modal. Riba' berlaku bagi bunga dalam segala bentuk dan dilarang karena dampak negatifnya yang mengganggu perekonomian.

Sebagaimana al-Gazali menitikberatkan pada institusi perbankan dari sudut transaksi perekonomian melalui dua jalur yang berlainan: 1) jalur transaksi ekonomi, yang dihubungkan dengan dunia perdagangan, perbankan dan juak beli; 2) Jalur negara, yaitu pendirian institut perbankan untuk menjamin mata uang yang beredar dan untuk pemenuhan kebutuhan rakyat (meliputi Baitul mal al-Khas dan baitul mal). ${ }^{19}$ Al-Gazali sangat keras dalam memperingatkan supaya lembaga-lembaga penting negara jangan sampai terjerumus kepada riba' sebagai larangan keras Tuhan.

Namun oleh Coulson justru menghendaki masyarakat Islam dibawa ke dalam garis kerusakan masyarakat Barat, dimana segala transaksi-transaksi spekulatif yang termasuk jenis penjudian menjadi realita yang ada yang lazim, dimana hukum adalah budaknya dan hukum dalam keadaan yang terus berubah.

Coulson lebih tajam menyalahkan syari'ah dalam sudut pandang idealisme syari'ah. Menurutnya, mengenai sistem hakim, dapat dikatakan bahwa dalam syari'ah ada consilium yaitu yang terdiri atas sejumlah ulama yang membantu hakim dan memberikan nasehat pada hakim dalam menanggapi

\footnotetext{
${ }^{18}$ Muhammad Moslehuddin, op. cit., h. 177.

${ }^{19}$ Zainal Abidin Ahmad, Dasar-dasar Ekonomi Islam (Jakarta: Bulan
} Bintang: 1979), h. 301. 
kesulitan-kesulitan hukum timbul suatu kasus. Consilium ini dapat dihadirkan ketika kasus dibuktikan. ${ }^{20}$

Untuk lebih jelasnya tentang prosedur ini, ada beberapa pertanyaan yang patut dijadwal oleh syari'ah sebelum Coulson menanggapi. Apakah seorang hakim berhak menilai persaksian yang berada dihadapannya atau hakim berhak menilai persaksian yang berada di hadapannya atau hakim dibatasi untuk memberikan keputusan sesuai dengan keputusan itu saja. Untuk menjawabnya, ada dua pendapat mengenai masalah ini. Yang pertama, berpendapat bahwa seorang hakim harus memberikan keputusan sesuai dengan kesaksian mereka tanpa ragu-ragu atau penilaian. Pendapat kedua, menganggap persaksian tidak lebih dari suatu cara untuk memastikan atau menentukan kebenaran, sehingga seorang hakim berhak untuk menilainya dan memberi keputusan sesuai dengan penilaiannya. ${ }^{21}$

Sebagai jawabannya, syari'ah mengambil jalan tengah dan menganggap persaksian mengikat seorang hakim. Hakim harus memberikan keputusan tanpa penundaan, karena keadilan yang ditunda merupakan keadilan yang ditolak. Namun hakim dapat menangguhkan pengumuman keputusan atas permintaan si penuntut atau untuk mengadakan penyelesaian secara kekeluargaan. Prosedur ini amat efektif dan logis, karena hakim walau menunda keputusan dikarenakan menilai kesaksian, yaitu diberikan kesempatan pada tingkat yang pertama. Dimaksudkan untuk menjamin bahwa kesaksian-kesaksian itu adalah benar yang telah memenuhi prasyarat-prasyarat yang sudah ditentukan untuk menerima kesaksian termasuk saksi yang dapat dipercaya" memberikan bagi hakim keleluasaan untuk menolak saksi karena berkelakuan buruk. Prosedur sebagaimana di atas membuktikan efesiensi pengadilan. ${ }^{22}$

\footnotetext{
${ }^{20}$ Consilium ini dapat dilihat yang telah dipraktekkan peradilan biasa dalam Islam terdiri atas seorang hakim atau lebih. Al-Jauzi menceritakan kasus praktis yang menggambarkan metode kolegial: bahwa"Ubaid Allah alAnbari dan Umar ibn Amir adalah qadi Basrah; mereka bertemu dan samasama memecahkan perkara hukum sebelumnya. Lihat Muhammad Moslehuddin, loc. cit.

${ }^{21} \mathrm{Op}$. cit., h. 172-173. Lihat pula Fathurrahman Djamil, Filsafat Hukum Islam (Cet. II; Jakarta: Logos Wacana Ilmu, 1997), h. 62-63.

${ }^{22}$ Ibid., h. 175.
} 
Namun oleh Coulson memberi komentar bahwa sistem prosedur dan pembuktian sengaja membatasi lingkup kebijaksanaan pribadi hakim dalam menemukan fakta.

Contoh lain yang menggambarkan tentang pemahaman Coulson yang salah mengenai hukum Islam. Dengan menunjuk suatu wilayah Islam, Jazirah al-Maghrib di Afrika Barat Laut, Coulson mengatakan bahwa adanya model tuan tanah yang tersebarluas berdasarkan kontrak tanah pertanian, dimana tuan tanah menyewakan tanah kepada si penyewa dengan imbalan. Adalah bagi hasil dari produksi tanah tersebut. Bagi hasil dari produksi itu adalah seperlima (khamessa), menurut syara'kontrak atau khamessa ini tidak dibenarkan karena sewa menyewa ini terlalu tidak pasti; pertama ia terdiri atas bahan makanan yang bisa mengalami naik turun tergantung harga pasar, kedua, nilai harga bagian seperlima tergantung pada kualitas hasil panen yang tidak diketahui pada waktu kontrak ditandatangani. Mengacu pada pendapat para ulama, jenis kontrak ini penuh dengan resiko dan spekulasi. Meskipun demikian, kontrak khamasse dipraktekkan secara luas sebagai kebutuhan ekonomi bagi masyarakat yang memiliki sedikit modal, dan meskipun oleh para qadi' Maliki sendiri mengakui keabsahannya dikenakan berdasarkan kebutuhan. ${ }^{23}$

Oleh Coulson kasus model kontrak bagi hasil khamasse tersebut menurutnya menunjukkan bahwa idealisme syari'ah harus tunduk kepada realisme yaitu kebutuhan msyarakat. Coulson merujuk pendapat-pendapat ulama yang menganggap bahwa khamessa penuh dengan resiko, yang juga merupakan suatu perujukan kepada pendapat ulama yang sama sekali bukan merupakan hukum syara' namun Coulson menyamakan hukum dengan pendapat ulama.

Coulson menyalahkan idealisme Syari'ah, karena menurutnya realisme adalah keadaan masyarakat sekarang dimana syari'ah harus menyesuaikan diri dengannya. Namun, dipahami bahwa realisme hanyalah fenomena yang berubah, yang pada kenyataannya adalah perubahan-perubahan.

\footnotetext{
${ }^{23}$ Ibid., h. 176.
} 


\section{PENUTUP}

Coulson melihat munculnya konflik dan ketegangan dalam hukum Islam, pada apa yang dia pahami sebagai upaya untuk memahami kehendak Tuhan yang dilakukan oleh para ulama. Ia menemukan bahwa "yurisprudensi Islam adalah seluruh proses aktivitas intelektual yang memastikan dan menemukan ketentuan-ketentuan kehendak Tuhan dan mentransformasikannya ke dalamnya sistem hak dan kewajiban yang secara hukum dapat dilaksanakan. Tetapi preseden yang harus diikuti dan untuk melaksanakan hak maupun kewajiban tersebut kecuali jika ia benar-benar sesuai dengan nash (alQur'an dan sunnah).

Pandangan Coulson tentang konflik dan pertentangan yang ada pada kutub idealisme dan realisme adalah bahwasanya hukum Islam merupakan hukum yang bersifat idealistis dan jauh dari realisme masyarakat dan apa yang hendak dikatakannya ialah bahwa hukum Islam ditentukan oleh fakta-fakta sosial yang diturunkan pada posisi hukum buatan manusia. Hal ini jelas bertentangan dengan ideologi Islam, hukum Tuhan tidak bisa dikompromikan dengan hukum manusia karena akan menghilangkan tujuan hukum untuk mengontrol masyarakat.

Sehingga penilaian keliru Coulson terhadap yurisprudensi Islam disebabkan ketidakmampuan Coulson membedakan antara pendapat fuqaha dan hukum itu sendiri, dan perbedaan antara doktrin hukum dengan praktek hukum serta antara tugas fuqaha dengan tugas hakim. 


\section{DAFTAR PUSTAKA}

Ahmad, Zainal Abidin.Dasar-dasar Ekonomi Islam. Jakarta: Bulan Bintang: 1979.

Ash-Shiddieqy, T. M. Hasbi.Fakta Keagungan Syari'at Islam. Cet. II; Jakarta: Tintamas, 1982.

Djamil, Fathurrahman.Filsafat Hukum Islam. Cet. II; Jakarta: Logos Wacana Ilmu, 1997.

Maslehuddin, Muhammad.Philosophy of Islamic Law and The Orientalist A Comparative Study of Islamic Legal System. Lahore: Ashfaq Mirza, Mg. Director, Islamic Publication Ltd., t. th.

Minhajuddin. Pengembangan Metode Ijtihad dalal Perspektif Fiqih Islam, dalam Pengukuhan Guru Besar Terbuka Luar Biasa IAIN Alauddin, 2004.

Nasution, Harun. Teologi Islam: Aliran-aliran, Sejarah dan Perbandingan. Jakarta: UI Press, 1986.

Perpustakaan Nasional RI. Ensiklopedi Hukum Islam. Jilid 2. Cet. V; Jakarta: PT. Ichriar Baru Van Houve, 1997.

Al-Syatibi, Abu Ishak. Al-Muwafaqad fi Ushul al-Syari'at. Mesir: Maktabah al-Tijariyah al-Kubra, t.th.

W. Montgomery Watt.Islam and The Integration of Society. Edinburgh: University Press, 1972.

Zuhri, Muh. Hukum Islam dalam Lintasan Sejarah. Cet. I; Jakarta: PT Raja Grafindo Persada, 1996. 